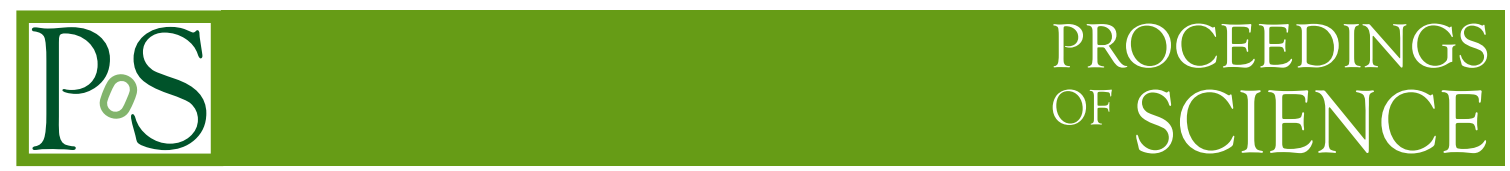

\title{
Hans Bethe on the occasion of his 100th birthday
}

\section{Robert Brout*}

Physique Théorique, Université Libre de Bruxelles and

International Solvay Institutes,

Boulevard du Triomphe, ULB - C.P. 225, B-1050 Bruxelles, Belgium

E-mail: rbrouteulb.ac.be

Opening

Bethe Ansatz: 75 years later

October 19-21 2006,

Brussels, Belgium

${ }^{*}$ Speaker. 
It is an honor to talk about a great man, and a fine man, before friends and colleagues. I thank the Solvay Institute and Marc Henneaux for giving me the occasion to do so. In view of my friendship and family ties with Hans Bethe, Marc and I thought that it would be appropriate that these few biographical remarks should be more anecdotal than scientific in content, especially in view of the fact that Bethe's science will be the subject of talks at this conference.

My wife Martine, was the cousin of Han's wife, Rose, nee Ewald. I had met Martine in the fall of 1952 when I was doing my doctoral research at Columbia. One might imagine my sense of awe when Martine proposed a visit to Ithaca to introduce me to her family, and in particular to her illustrious cousin-in-law. It was the Bethe family that welcomed, lodged and boarded Martine when she came to America at the end of World War .II. Ties and loyalty between the Bethes and Ewalds have always been maintained throughout the years, and I might add, throughout the world where so many were scattered following the diaspora of the German intellectual class during the years of Nazi domination.

Upon arriving in Ithaca I found the Bethes more then welcoming. Hans, to some, might have given the impression of being somewhat forbidding. This may be attributed to a certain social awkwardness, for example often accompanied by a hoarse clearing of the throat which could have been interpreted as a gesture of impatience or of disapproval. But no, such sentiment was in no way part of the character of Hans Bethe. He was a warm, generous person, quick to recognize the positive qualities of others and quick to offer his help to others. Nonetheless he was not naïve, nor did he let himself be taken in. For all his natural impulse of generosity as far as I could see, his judgments were always realistic and objective. And often he was put into a position where he had to judge.

Within a few hours of our arrival, Hans invited me into his large office, furnished with a very large desk. This was necessary to harbor his vast stamp collection. As he grew older, this wonderful collection occupied an increasingly large portion of his time. It complemented his very considerable knowledge of geography and history. There were few books, for I soon learnt that there was no need for books. He had all in his head that he needed to know to do what he did and that was a lot. If per chance he did require something, more often than not he would ask a colleague to transmit it verbally. He was quick to catch on.

After inquiring of me about my thesis subject, he took a look at my calculations -Ü a scheme to estimate inelastic cross sections for the excitation of internal degrees of freedom of molecules and how this was reflected in the propagation of sound. Of course he knew all about that and after suggesting some technical improvements, to my surprise he gave me from his files a report that he and Teller had written ten years previously on how these inelastic collisions influenced shock wave profiles. In this way, from the beginning, like so many, I became a Ş Bethe influenced ̌̌ student. He always gave his help without stint.

After doing some physics, in good European fashion, the whole family took a nice walk through the beautiful woods that surrounded Ithaca and that Hans loved. He was a famous walker and a lover of mountains. He kept his legs in fine shape to a very advanced age, disdaining the use of the elevator of Newman lab, always walking the stairs to his office which was on the top most story.

It was during this visit that I had the pleasure to experience Hans'wonderful sense of humor. He was a great admirer of the British sense of whimsy and fantasy. He read Dickens throughout 
his life and I have been told that when he and his young son took baths together, Hans would sing humoristic English songs in his deepest of deep bass voices.

The fall that I came to Cornell, Keith Bruckner gave a seminar reporting on the calculation he did with Murray Gell-Mann on electron correlations in metals. In conclusion, Bruckner emphasized that there was no sign of the role of plasma oscillations in these calculations. Yet, previously, David Bohm and David Pines, had given convincing arguments that the rigidity of the electronic system resulting from the high value of the plasma frequency was the key factor responsible for the interesting physics of this system. When finally I could look into the matter during the Christmas recess, I could see that the two methods were physically equivalent, but presented in different mathematical guise. When I showed that to Hans he was very enthusiastic. This was the period when he was much involved with the nuclear many body problem, but he had some time to look into the electron problem as well. As he was invited to give a talk on the many body problem few weeks later, he saw to it that I got financial support and he took me along with him. Then when he gave his talk he called upon me from the podium to come up and show what I had done. That was his way Ú to see that young people under his wing would advance and be recognized. As I say, - a person of rare generosity.

Of course, one could talk about Bethe for hours, but other business calls us. So I shall close this brief discourse with emphasis on one particular character trait of this remarkable person, a trait which I value above all. That is his social and political responsibility.

Bethe accepted a key position in developing the atomic bomb, this in response to the call of Oppenheimer and the approval of Einstein. It was conceived as the only possible way to confront a very real, truly frightening threat, the potentiality of what might have happened had the Nazis developed the bomb. And it was known that they were working on it. After the war, Hans Bethe accepted to the full what he considered to be his responsibility, given his role in the development of atomic weapons. His contributions to the cause of peace were immense. His contributions, against very considerable opposition from both sides, to the elaboration of the nuclear test ban treaties between the US and the USSR were essential and instrumental. Moreover, he was instrumental in the development of peaceful uses of nuclear power. In particular, he was the leading figure in the development of safety programs for reactors. Also he was perhaps the leading figure in launching the Bulletin of Atomic Scientists whose mission was to further peace in a world which was then under a state of great tension.

I think if one had to characterize the man Bethe, one of the great intellects of our time, the man who saw to it that quantum mechanics really works be it solid state, atomic, nuclear, particle, or astrophysics, one should set above all else, his generosity of spirit and his sense of responsibility to humanity. 